\title{
Agricultural Development And The Role Of Women's Self- Employment In Pakistan
}

\author{
Rummana Zaheer \\ \& \\ Saman Hussain \\ Department of Economics \\ University of Karachi \\ Muhammad Nadeemullah \\ Department of Social Work \\ University of Karachi
}

\begin{abstract}
Pakistan aimed to achieve the target of 5.5\% of GDP growth for the fiscal year 2015-16, of which $3.9 \%$ is expected to catch from the agricultural sector. In the economy, about $42.3 \%$ of the total employment is attributed by the agricultural sector, of which about $72.7 \%$ is contributed by the $48.96 \%$ of the total population, the WOMEN. Female as first-line labor force never receive the consideration of their actual contribution in the development on national basis. Like other developing economies of the world, Pakistan must to focus to expose and utilize the potential of the women labor force in agriculture. The discussion on the agricultural development of Pakistan with reference to women's self-employment is done in this study. Along review of literature and empirical studies, to facilitate the discussion and conclusion, annual time series data from the period of 1985 to 2015 under the regression analysis is taken. The variables taken, to discuss the strength and nature of association with the agricultural development of Pakistan by selfemployment of women, are gross domestic product of agriculture, literacy rate of women, women employed in agriculture and domestic credit disbursement to agriculture sector. The study expects the significant result withal positive association of variables to the development of the economy.
\end{abstract}

Keywords: Women, Self-Employment, Agriculture, Economic Development, Financial Assistance.

$$
\begin{aligned}
& \text { تخدص }
\end{aligned}
$$

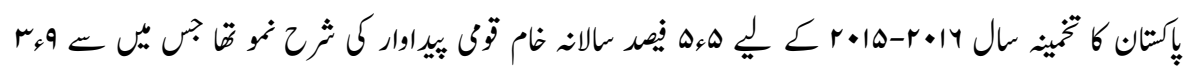

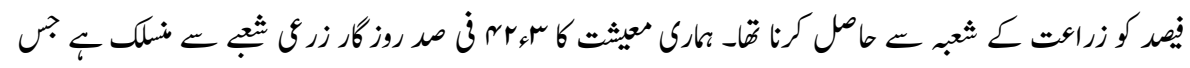




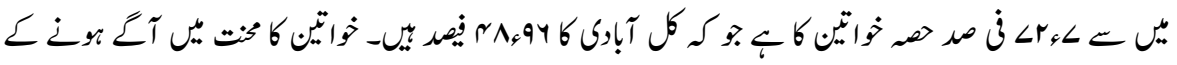

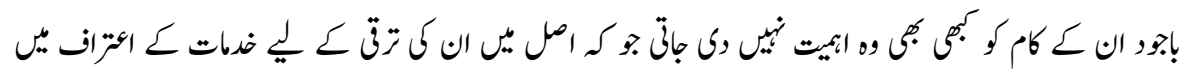

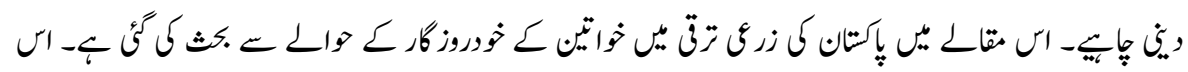

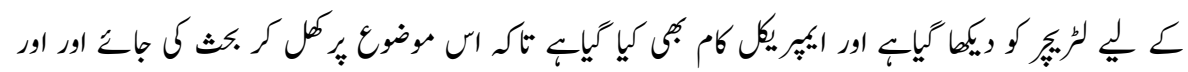

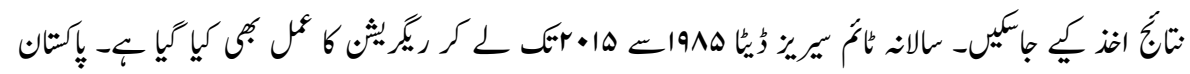

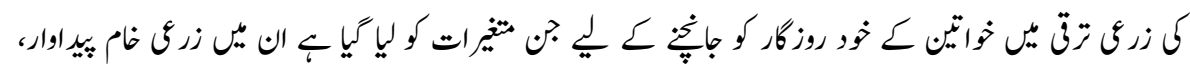

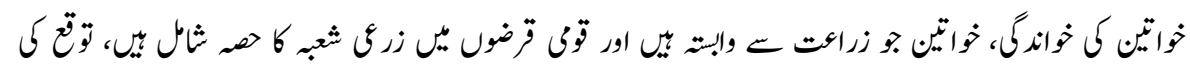

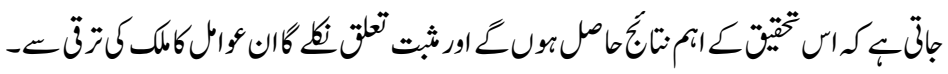

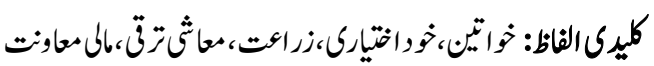

\section{Introduction}

"What I learn from talking to so many women around the world: If you can empower them with the right things, the right tools, they can lift up their family. And that ultimately lifts up their community and their society" — Melinda Ann Gates ${ }^{1}$

The GDP growth of the year 2014-15 is recorded as $4.24 \%$ (the highest achievement since 2008-09). Pakistan's finance minister declared to expect the target of the developmental growth as $5.5 \%$ for the fiscal year 2015-16 which continues to grow to be $6 \%$ and 7\% for the fiscal year 2016-17 and 2017-18 respectively. The declared target of GDP expects the contribution of 3.9\% from the backbone of the economy, the Agriculture. The agriculture sector currently supports the growth with a contribution of $20.9 \%$ to GDP along contributing to the employment as $42.3 \%{ }^{2}$ of the total employment in the economy (Economic Survey of Pakistan 2014-15), of which about $72.7 \%$ is the contribution of the $48.96 \%$ of the total population, the WOMEN (Labor Force Survey 2014-15, Pakistan Bureau of Statistics).

In the sector four distinct categories of employed female exists: employer, own account worker, non-paid family worker and employees. Only $0.1 \%$ of the employer's ratio in total employment is forwarded by females and $24.9 \%$ are getting remuneration in terms of cash and commodities as being employees. $20.4 \%$ are working on own account. It is very interesting to eyed that a significantly larger contribution in employment are of 
female for $54.5 \%$, are those, who worked to help their family without any payment: the non-paid family worker. The contrasting figures of employer, employee and non-paid workers are highlighting the path to enhance and facilitate the female labor force in terms of technical and financial assistance so, the last two categories may diversify their objective to the category of the Employer so the sector may enabled to earn more. As the employment ratio of women in agriculture is significantly larger it is definite that work done on the self employment of women will be sound.

The financial assistance is getting serious attention in agriculture as the credit disbursement in the sector by banks is accounted for PKR 326 billion as $65.2 \%$ of the target for the fiscal year 2014-15. It is observed that this disbursement is $27.5 \%$ higher as compared to preceding year. To score the above stated finance minister's declared mark, many redeems for financial assistance has been announced and are in process too, among these the promotion of the concept of self-employment is under practice with serious attention $^{3}$. Where the finance facilitate the many, literacy lacks the others. As far the technical assistance is concerned the literacy rate of female is accounted much.

The agricultural activities are in practice in the rural areas of Pakistan where a very little efforts are done for the degree education and technical training of agricultural activities of females that's the reason of having more first line female labor force in agriculture as compared to the other sectors (Faridi et.al. 2011). On the one end degree education resists the women to work as self employed, on the other end, the illiteracy limitate them in their vision of work and bound them to remain as less or non-paid. It is observed that the literate women are more capable to reap the fruit of investment and accomplish the task with more agricultural yield. It can be said that by promoting the literacy among the females and spreading the dimension of agricultural disbursement will ultimately raise the productivity of agriculture.

The ratio of women labor force in rural areas and credit disbursement to agriculture sector clearly represents their significance to economic growth and particularly the agricultural growth leading towards food sufficiency, poverty eradication and foreign exchange earnings. But unfortunately the agriculture sector did not receive the attention as much as it required on both the ends of financial and technical assistance. Furthermore the always neglected gender strata in Pakistan - Women labor force did not receive the needed attention at national level despite of its significance towards productive growth of economy. In previous researches as found in literature, not focusing on self-employment of women in agriculture sector as it has tremendous potential leading to economic development. What this study aims to do, is to find the association of literacy rate and 
availability of credit along technical knowhow of women labor force, that not only motivate them to have their laboring practices in a more commercial intention but taking it into broader view, also uplift the rural marginal class by involving them in economic growth. Thus, this study evaluates the significance and effectiveness of women labor force towards the agricultural development by promotion of financial and technical assistance.

\section{A Brief Performance History of Agricultural Sector}

The major objective of the agricultural sector to the economy of Pakistan is of provision of food security and maximization of agricultural yield leading to utilization of its export potential and reducing deficit in current account balance.

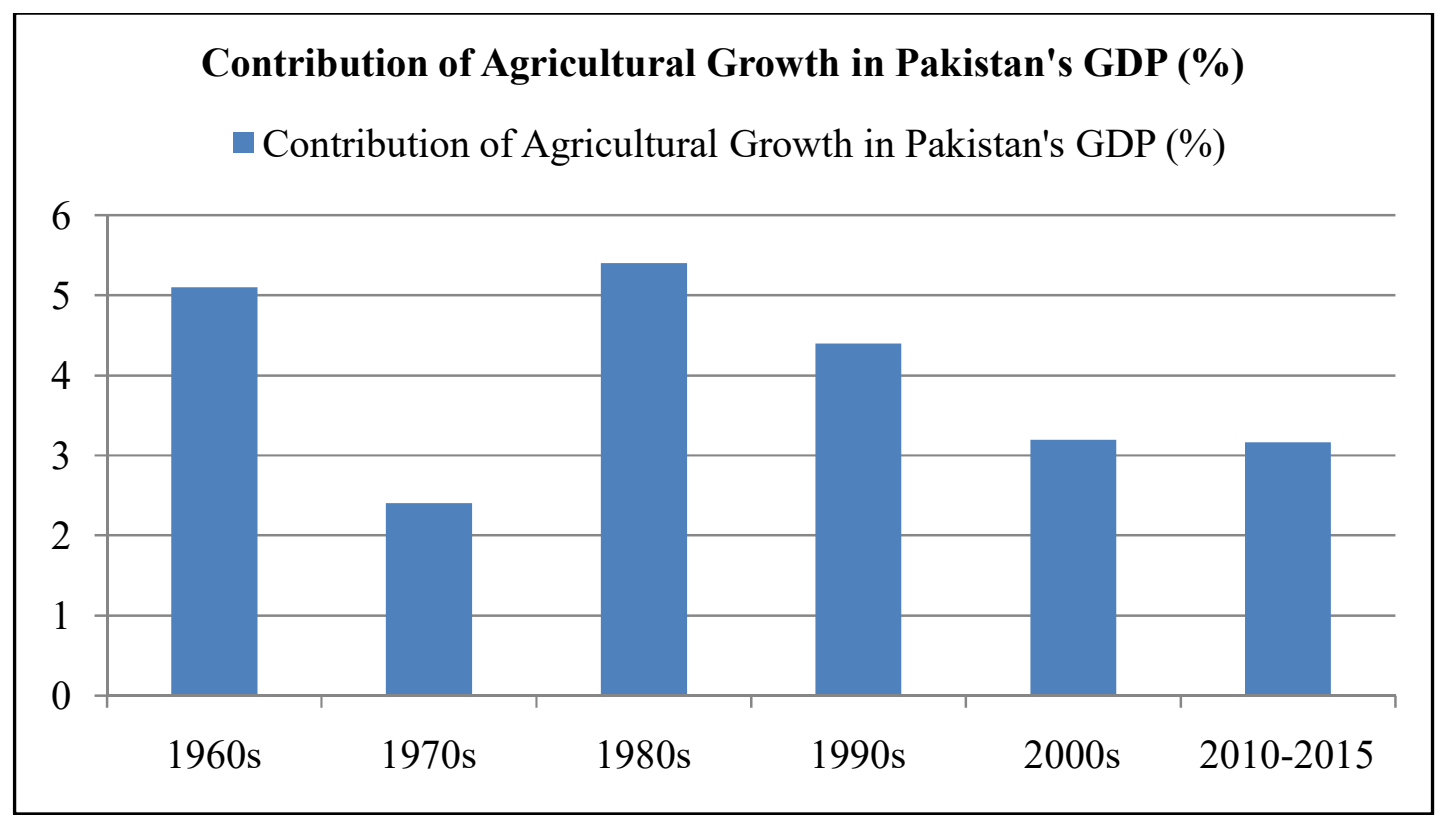

Data Source: Federal Bureau of Statistics.

In the decade of $1960 \mathrm{~s}$, the agriculture sector was contributing $5.1 \%$ at an average to the Gross Domestic Product of Pakistan. In 1970s there was a decline in the sector's contribution towards economy' GDP by $2.7 \%$ and it reached at an average rate of $2.4 \%$ for the said decade. The most highest achievement in the sector is recorded in era of $1980 \mathrm{~s}^{4}$ by increasing an average rate of $3 \%$ and reached at $5.4 \%$. In 1990 s, once again a decline could be eyed by $1 \%$ at average and fallen at the level of $4.4 \%$. The decade of $2000 \mathrm{~s}$ is once again declined and 
fallen at the average rate of $3.2 \%$. The current regime consists of five years having the growth as $3.16 \%$ which is far behind the targeted mark of the growth in the sector.

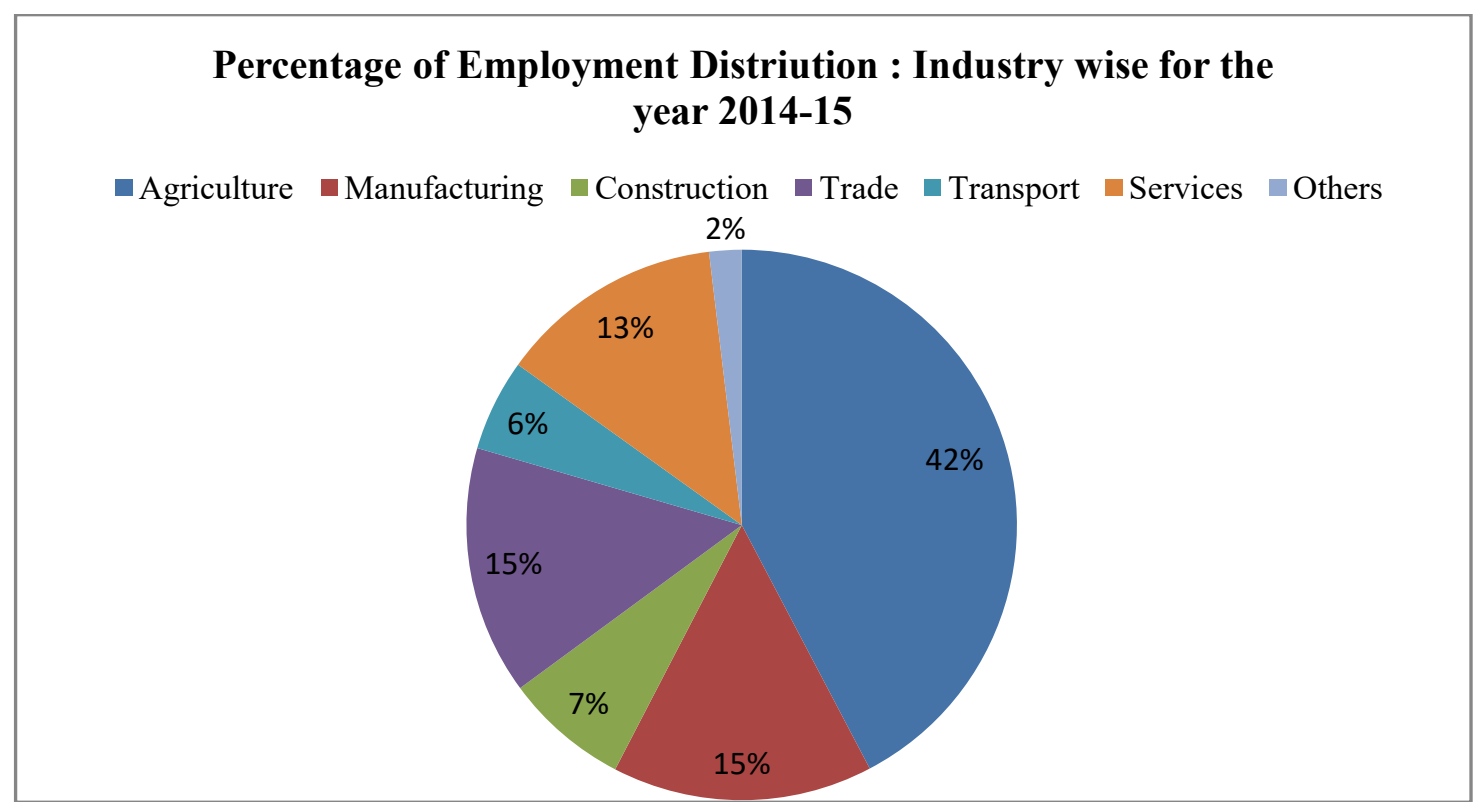

Data Source: Economic Survey of Pakistan 2014-15.

The agricultural sector enfolds $42 \%$ of the total employment including the sub-sectors of crops, livestock, forestry and fishing, where crops attributed for $5.2 \%$, livestock for $2.2 \%$, forestry for $2.6 \%$ and fishing for $2.6 \%$ in the productive yield of the sector for the fiscal year 2014-15.

\section{The Role of Women in Agriculture}

In Pakistan, rural women has a major and idiosyncratic role in food security. The women labor force participating behind the agricultural production are prominantly very high as compared to men labor force. The sector 's productivity enjoying the efforts done by $72.7 \%$ of women and $27.3 \%$ of men labor force of the total employment in the sector( Economic survey of Pakistan, 2014-15).

The rate of participation of Pakistani women labor force has raised over the last three decades while their involvement got intensified in agriculture sector. The participation of women labor force in the sector is very hard-hitting as they perform plentiful labor tasks like grass cutting, picking, sowing, harvesting, weeding and post-harvesting. Their work participation could be seen at wider horizon during thwe sowing and harvesting farming 
seasons.Along farm fields work they perform in allied fields too. They work for livestock keeping like managing feed of animals, milking, processing of milk, obtaining biproducts of milk like ghee, butter, and lassi etc. for commercial basis and for fullfilment of food requirements at home. A Pakistani women spend about 15 hours/day in agricultural activities performance majjorly in crop and livestock. They use forest for essential household tasks likewise collection of wood to get house warm and cooking food and collection of fodder for livestock keeping. In the sector of fishery they perform post fishing activities like processing and preserving of fish and shrimps. They do not move for fishing but participate by working on fishing net and fish carrying baskets.

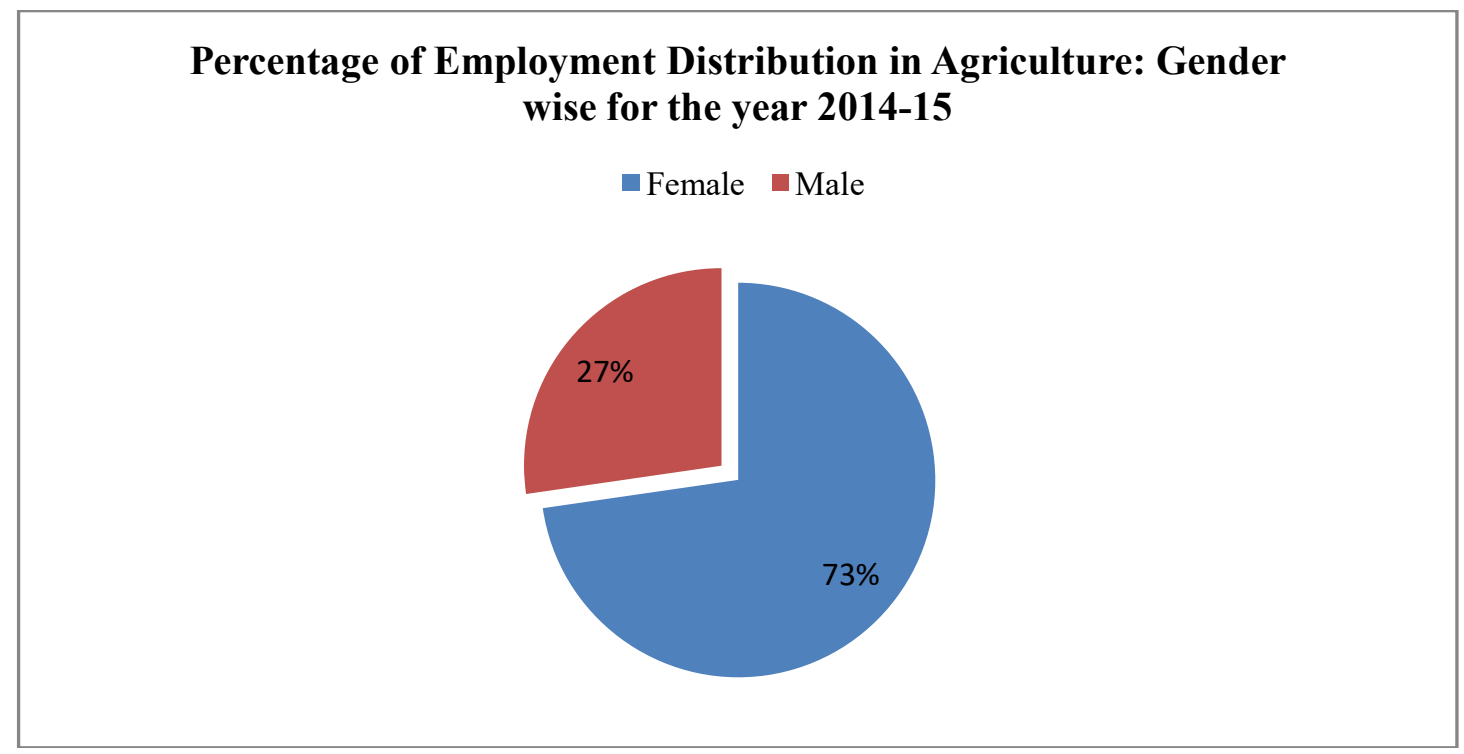

Data Source: Labor Force Survey of Pakistan 2014-15.

The ability to meet $100 \%$ food requirements of the sector's yield is due to lack of credit assistance, lack of technical assistance to latest equipment information and other technologies needed for increasing productivity, socio-cultural constraints like male domonance and other traditional beleif system (Butt et.al. 2010).

\section{A Brief Trend of Credit Disbursement to the Agriculture Sector}

In Pakistan landholding patterns are mostly owned by small farmers where women labor force found as being owners and non-paid family workers. Financial detrimental high in effects for small land owners. It is not easy to access the bank for loan as collateral needed to be acceptable are not in their range. 


\section{Agricultural Credit Disbursement in Pakistan}

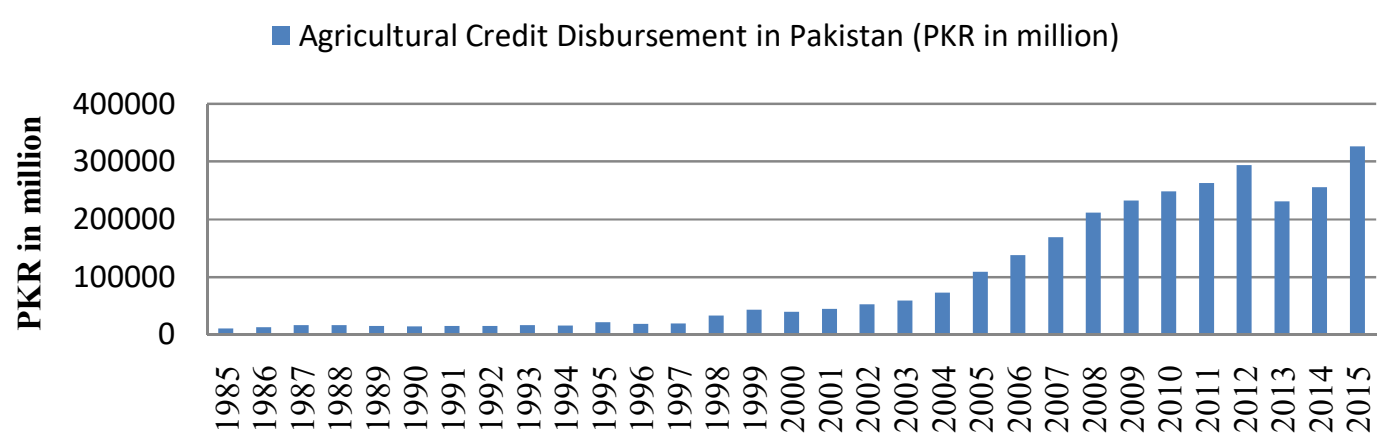

Data sources: 1. Adopted from Abdullah, et al. (2015). 2. Figures for the years 2014 and 2015 are taken from Economic Survey of Pakistan 2014-15.

During the period of 1985 to 1988, the lending institutions including banks and other financial supporting institutions raised their credit disbursement by $35 \%$ to the agricultural sector. The next two fiscal years of 1989 and 1990 the credit disbursement declined by $9.6 \%$ and $4 \%$ of the very previous year. A slighter increase is observed in availed mark of credit disbursement in the year 1991 and reached to PKR 14915.29 million by an increase of $6.8 \%$. In 1992 a decrease of $2.9 \%$ of the preceding year is disbursed in the sector. In year 1993 disbursement reached its most highest mark of the preceding years at PKR 16198.31 million in the sector. In 1994 credit disbursement in the sector declined by $5.01 \%$ of the preceding year. in year 1995 second highest disbursement has marked of the history of PKR 21965 million. In year 1996 a slighter decline of $13.03 \%$ and in 1997 a slighter increase of $2.16 \%$ is registered. In year 1998 a prominent increase is registered in disbursement of PKR 32974 million. In year 1999, an increase of $29.94 \%$ as compared to previous year had been recorded by lending institutions. at the beginning of the $2000 \mathrm{~s}$ a decline of $7.37 \%$ as compared to the year 1999 in the disbursement of credit is recorded. An increase of $12.85 \%$ of the preceding year had been recorded in the year of 2001. The next three years of 2002, 2003 and 2004 showed an increase of $17.09 \%, 12.33 \%$ and $24.66 \%$ as compared to correspondence years. The whole decade followed an increasing trend of disbursement of credit to the sector as year of 2005 for $48.04 \%, 2006$ for $26.43 \%, 2007$ for $2.8 \%, 2008$ for $25.3 \%, 2009$ for $10.13 \%, 2010$ for $6.48 \%, 2011$ for $6 \%, 2012$ for $11.7 \%$, while the year of 2012 showed a decline of $21.37 \%$, and once again an increase of $10.6 \%$ in year 2013, 2014 for $27.47 \%$ as compared to the respective preceding years. The agricultural credit disbursement for the year 2014-15 is the most highest figure of sector's history as PKR 500 billion( it was 380 billion for the preceding year) of which $65.2 \%$ is achieved as targeted. The disbursed credit to the sector constitutes $52.1 \%$ of farm credit of which $16.5 \%$ is accounted to 
small-scale farms and $31.3 \%$ is to large-scale farms while $47.9 \%$ of nonfarm credit. The disbursement activity of credit to agriculture is performed by 5 Commercial banks, ZTBL, 15 DPBs, PPCBL, 7 MFBs and 4 Islamic Banks of the country( Economic Survey of Pakistan 2014-15). Now likewise Cambodia, India, Indonesia, Malaysia, Philippines, Thailand and Vietnam contract farming is being practiced in Pakistan for the output of maize, potato, rice, sugarcane and tobacco etc (Habib ,2015).

\section{Literature Review}

The effectiveness of women's self-employment to the prosperous growth of agriculture sector for developing countries is a potential debate topic. Many researchers worked on gender wise self-employment and its effects on the economy, along this some others discussed the women labor force in agriculture sector of developing economies. The relationship of the women's self-employment and their significant role in agriculture possess many opportunities as well as constraints. The significance of agriculture for the development of Pakistan's economy is very clear and sound (Butt et al.2010).

\section{Women Labor Force and Self-Employment in World}

If the studies regarding intensions to be self employed in labor force are reviewed, it is find that there are two ends of self-employers; the opportunity self-employer and the necessity self-employer. The opportunity self -employer pursue an opportunity in the economy and enter into self-employment while necessity self-employer shifts into selfemployment due to lower returns in wage sector (Block \& Wagner, 2006).

The higher level of unemployment is not the driving factor for entrepreneurship among low skilled labor. The lower level of employment declines the opportunity self-employment. The higher will be the propensity to self-employment the lower will be the low-skilled labor and possess the strong correlation between the economic growth and selfemployment with respect to credit availability (Deli, 2011). While measuring the tendency of low-skilled men and women labor force towards self-employment in US, it is concluded that low-skilled labors are more tend to penetrate entrepreneurial world instead of degree holders especially in case of women but the economic rewards are not as impressive as in the case of men labor force. Promoting the self-employment among the women (not having a degree education), may not bring the fruit of socio-economic well-being as rise in number of dependents bound them to opt work-care choice (Lofstrom, 2009).

The developing economies in order to grow rapidly towards economic prosperity, more tend to promote the concept of self-employment as they lack in: higher education, proper channelized credit disbursement, per capita income and nuclear family structure. That's the reasons that women on formal jobs in emerging economies are lesser in ratio as compared 
to self-employment (Faridi et.al. 2011). Unemployment and poverty raises the concept of self-employed women in the economy. The developed economies where women are frequently appearing in higher education system, women are frequently seen on formal job position. Developed economies lack in the concept of self-employment. There the women's empowerment discussed as more than the self-employment in work. It is another fact that the deprived labor market condition is also responsible for self-employment in the economy. While in recession, the lenient availability of credit to private sector helps the economy to overcame the constraint of unemployment (Fairlie, 2011).

On one end, high education positively influence the entrepreneurial skills that ultimately urges the willingness to be self employed but on the other hand higher education raise the chances to avail the higher remuneration posts that discourages the self-employment sector (Le ,1999). Higher degree education as key driver for self employment. The propensity to be self employed is higher in higher educated strata than of the lower educated strata (Rees \& Shah, 1986, Borjas \& Bronars, 1989 and Evens \& Leighton, 1989).

In the labor market of Vietnam the different trends of shifting are observed from wagelabor to self-employed for men and women labor force. The determinants discussed in the study finds that earning differentials (from wage to self employment) significantly influence the self-employment in women. The no. of dependents in the family positively affects the women labor force switching towards self-employment. The education attainment positively affects the concept. Financial assistance raise the risk bearing consciousness among the women and their intentions to be self employed (Trang \& Duchene, 2008).

\section{Women's self-employment in agricultural sector of Pakistan}

The factors affecting the performance of women labor force as self-employer leading to the higher productivity of the agricultural sector are education, family members and health (Georgellis \& Wall, 2004 \& LeAnht, 2000).

The productivity constraints faced by Pakistani women in agriculture, if discussed, highlights the difficulties to access the latest technology because of the low literacy that is most common in almost every rural region of the economy. Women in rural areas are not much capable to get training on latest technical basis consequently are encountered the low productivity. Along low literacy rate other factors responsible for low productivity at women owned farms are lack of health facilities, benightedness of latest technique, difficulty to reap the benefit of financial institutions, ignorance of the segregated economic reforms on national level and low wages in rural areas are mainly responsible for the low productive yield of women in agriculture(Begum \& Yasmeen , 2011). 
There is an association between agro-growth and nutritional requirements. The choices of women labor possess in agriculture are as work and care, and the empowerment of women with reference to their choice of work-care. It is very interesting that as women in rural areas have more no. of dependents tends to care but economic deprivation compelled them work oriented in order to fulfill the nutritional requirements of their own and households (Balgamwala et.al. 2014). The reason behind the increasing number of women labor force in rural areas working in agriculture, is found as the migration of male member of the family to abroad for earning make the female members able and necessary to work out. The remittances from the abroad also strengthen them to utilize the domestic resources. Livestock and vegetable harvesting confirms the availability of food requirement by their own and vigorous source of their income too (Khan, 2007).

The significance of women labor force in agriculture sector of Pakistan, is represented by the larger portion of the women labor force served the sector by cotton and vegetable harvesting, keeping livestock and weeding are in fact non-paid. Badin is studies as field where all the money earned by the family only belongs to men and women are non-paid workers while another study field of Shadadpur where the income generated from vegetable harvesting and livestock are in the hands of women. The significant difference in the productive yield of both of the study fields is dramatically favored the Shadadpur that empower the women in their job (Balgamwala et.al. 2015). Lack of technical knowledge and credit availability are the core reason that women labor force worked as non-paid worker not to earn but to fulfill the food requirements of the family. as the women get the degree education, their propensity to self-employment decreases and vice versa. Level of education is not the only hurdle for the females that not allow her to be familiar to the latest equipments and techniques to get more yield of their efforts in the sector (Khan, 2007). The lack of degree education and no. of dependents are significantly affecting the women's self employment ration in Pakistan (Faridi et.al. 2011).

Financial support interestingly proved to be hampering in case of low-skilled women labor force as compared to men (Lofstrom, 2009). The increasing trend in disbursement of agricultural credit will be an encouraging step for female entrepreneurs. The credit assistance is significantly effective for the agricultural sector's growth. Financial assistance in terms of improved and certified seeds, pesticides, modern equipment for farm related activities, fertilizers and liquid capital must be really helpful in getting rid of malnutrition and poverty in rural areas, but improvement in the entrepreneurial environment for small-scale agro based industries is seemed a factor that ultimately accelerates the economic growth (Khan et.al. 2011). Credit supply pursue the agricultural productivity, the livestock sector especially grows by more than $100 \%$. The unpaid family workers in agriculture are most critically registered than credit (Abdullah et.al., 2009). Micro credit impacts positively to the total output yield of vegetable and crop production at general and at particular wheat production (Arif, 2001). Micro credit does 
not only facilitate the yield of agricultural sector but the level of employment and standard of living among the masses also lift up (Waqar, 2002). The factor of financial assistance is broadly discussed in research studies. The financial endowment is a key constraint to self employment (Constant \& Zimmerman, 2006). The importance of credit as an essential to entrepreneurship is well recognized (Abdullah et al. 2015)

The betterment of nutrition could be driven by agricultural growth through women's work but it may also implied detrimentally. The two categories in agricultural growth are based first on agricultural yield and revenue and the other is implied by women work in the sector. Both of these categories affects the nutrition status. The prior one raise the improvement as raising the capacity to earn and consume while the later one influence positively but with less care time adversely affects the work health in the sector (Gillespie et.al. 2012).

Cultural and religious interpretations are the constraints that limit the mobility of women labor force and participation of this gender couldn't be eyed in its true horizon in agricultural sector (Prakash, 2003). Likewise other developing countries rural women labor force in Pakistan faces the socio-economic constraints like gender biasness, low degree education, inability to access prior opportunities etc. (Lal \& Khurana, 2011). Women labor force not only faced economic exploitation while trading commercially but some other socio-cultural issues also limitate their entrepreneurial activities (Balgamwala et al. 2015). A larger ratio of women labor force do not expand their productive activities as they are bound not to visit the markets, hence they are unaware about practicing business conditions (Begum and Yasmeen, 2011) likewise credit terms and profitable retail price (Khan, 2007).

\section{Methodology \& Model Specification}

To support the hypothesis, empirical analysis is done by growth model with time series data to discuss the agricultural growth along women's self-employment in the sector and the determinants that affect it. The data taken for the exogenous variables from various sources: agriculture, value added( $\%$ of gdp) under International Standard Industrial Classification (ISIC), revision 3, as proxy for the agricultural development is taken from WDI (World Development Indicators) ${ }^{5}$, literacy rate of females is obtained from Federal Bureau of Statistics Pakistan, credit disbursement to the sector is adopted from Abdullah et al.(2015) ${ }^{6}$ and Economic Survey of Pakistan 2014-15 and female self-employment rate is gathered from WDI and various editions of annual reports of Pakistan Labor Force Survey.

The model applied to the study is:

$$
\begin{gathered}
\mathrm{AGY}=\beta_{0}+\beta_{1} \mathrm{LR}+\beta_{2} \mathrm{CRDT}+\beta_{3} \mathrm{SLF} \mathrm{EMP}_{-}+\mu \\
\beta_{1}<0 \quad \beta_{2}>0 \quad \beta_{3}>0
\end{gathered}
$$


Where, $\beta_{0}$ is $\mathrm{Y}$-intercept, AGY is agriculture, value added ( $\%$ of gdp) of Pakistan, LR is the literacy rate of females in, CRDT is credit disbursement to the sector, and the SLF_EMP is rate of self-employment of female in the agriculture sector. $\beta_{1}, \beta_{2}$ and $\beta_{3}$ are parameters of the independent variables and $\mu$ is error term. The parameters are expected to have the positive signs for credit disbursement and rate of self-employment of females towards the sector's growth while the parameter for literacy rate is expected to have negative sign as its inverse relationship with the sector's growth behavior.

\section{Findings}

Table of descriptive statistics represents the nature of the data used in the study. Table 1 represents the maximum value for AGY (agriculture value added) studied in data is 27.3 while the minimum value found in data is 21.5, the maximum value for CRDT (credit disbursement to agriculture) studied is 168830.5 along the minimum value in the whole studied period is found as 19102, LR (literacy rate in females) stands highest in the studied period as $42 \%$ while the minimum literacy rate found in studied period is $29 \%$ and finally the SLF_EMP (ratio of self employment) got its peak at 77.9 while remains at lowest of 62.9.

Table: 1

Descriptive statistics

\begin{tabular}{|l|c|c|c|c|}
\hline & AGY & CRDT & LR & SLF_EMP \\
\hline Mean & 24.57692 & 63132.69 & 36.71308 & 71.49231 \\
\hline Median & 24.1 & 44789.82 & 38.57 & 74.3 \\
\hline Maximum & 27.3 & 168830.5 & 42 & 77.9 \\
\hline Minimum & 21.5 & 19102 & 29 & 62.9 \\
\hline Std. Dev. & 1.918399 & 47222.49 & 4.729772 & 4.737521 \\
\hline Skewness & 0.024848 & 1.147693 & -0.55616 & -0.3452 \\
\hline Kurtosis & 1.613128 & 3.111125 & 1.752352 & 1.718281 \\
\hline Jarque-Bera & 1.043186 & 2.860621 & 1.513355 & 1.148041 \\
\hline Probability & 0.593574 & 0.239235 & 0.469223 & 0.563256 \\
\hline
\end{tabular}

Central tendency of the data is measured by the tools of median and mean. AGY, agriculture, value added (\% of gdp) stands for the mean of 24.57 and median as 24.1 , the greater mean than its median shows the positive skewness of the variable. CRDT, agriculture credit disbursement has mean of 63132.69 and median of 44789.82 shows the positive skewness of the variable in hypothesis. The literacy rate of female likewise the other studies is negatively skewed as its mean 36.71308 is lesser then the median 38.57. Skewness of variables shown in Table - 1 clearly represents that literacy rate (LR) and self employment in females (SLF EMP) are negatively skewed while agriculture value added (AGY) and credit disbursement to the sector (CRDT) are positively skewed variables of studied model. 
Test applied to check normality of variables used in the model, is Jarque - Bera, shows that all variables are normally distributed. Kurtosis is applied here to describe the nature of variables in data as, CRDT (credit disbursement to agriculture sector) is laptokurtic showing long - tailed, while AGY (agriculture value added), LR (literacy rate of females), SLF_EMP (self employment in females) are short - tailed (platykurtic).

The empirical findings done in this study supports the hypothesis for the agricultural development. It is hypothesized to have an inverse relationship between the literacy rate and self employment as it is evident in literature to have higher literacy rate in labor force reduces the intentions to go for self employment and the empirical findings witnessed the same as the female literacy rate negatively affects the self employment rate of female. While credit disbursements is seemed to have support the financial needs of a self employment trend in labor force and found in study to have a positive association. And finally the development of agriculture as literature represents is accelerated by responding the sector's demand for finance also evident by our findings of having a positive association between the two.

\section{Recommendations}

In spite of being an agricultural country, the fact that $30 \%$ of Pakistan's population lives below the poverty line facing the food insecurity along $60 \%$ of its population living in rural areas where agricultural activities are suited much, reflects that some measures are seriously needed to be taken for removal of such contrasting conditions. Following are the recommendations for developmental growth of agriculture by exploiting the potential of women labor force in rural areas towards self-employment:

- Policy reforms are needed on regional, provincial and national level to encourage small-scale agricultural industries and handicrafts in rural areas.

- Set of arrangements that facilitates to trained the women farmers for farm related activities, livestock keeping along managing health, steps for effective water management for irrigation and livestock, and knowhow of latest technique and equipment used in agricultural activities.

- An encouragement should made on Government level for women farmers, to raise their farm's yield by offering subsidies, relaxation in tax system, zero-collateral based credit, availability of technological equipments to reduce the manual farm related tasks, market access and availability of certified seeds. This will not only lubricate the economy by a prominent growth rate but also helps the rural women to overcame the threat of food insecurity. 
- Design such programs on regional level that enable women farmers to be aware about preservation process of vegetables, crops, fruits and dairy products. Focus should be done especially on the ways to process the hide, skin and wool that ultimately bonafied for women farmers in rural areas along helps in poverty reduction in the economy.

- Introduction of the facilities on regional level so the women farmers may access the upgraded conditions of physical and socio-psychological health so they enable to participate well economically and socially.

- Initiatives to be taken on regional, provincial and national level to count the efforts of non-paid family women workers. It will not only helps in removal of social injustice but also enhance their self-empowerment that consequently raise the economic gains.

\section{Conclusions}

Likewise other developing economies Pakistan is mainly dependent upon agricultural activities not only to meet its domestic food requirement but also for providence of raw material to many industries. Pakistan as being the sixth most populous country of the world, have potential of its labor force in skilled, semi-skilled and unskilled laborers. But this potential could only be used if the both gender of labor force (women and men) are facilitated to essentials for entrepreneurship or for being employed.

The low productive yield of agriculture in Pakistan, reflects from the contrasting figures of its contribution to GDP and percentage in total employment of the economy. To improve that situation initiatives are needed for the encouragement of agricultural labor force. The ignorant part of the economy, female as first-line labor force, never receive the consideration of their actual contribution in the economic development on national basis. As being a developing economy, Pakistan must expose and utilize the potential of the women labor force in agriculture. Discarded equipments usage, lack of proper knowhow to operate the equipments, expensive latest tools, lack of awareness to use the latest knowledge and difficulty to access the market and bargaining prices are the core issues among the many, that the female labor force faced in the sector. The literacy rate and assistance in terms of credit are more valuable and seemed to be helpful for removal of the other constraints of the sector.

To promote the concept of diversification of women's efforts towards self-employment in rural areas, the effectiveness of education is found more concrete along the rising 
productive yield of the agriculture. The higher productive yield of the sector helps in removal of food insecurity, raising the economic performance on the level of employment, elimination of poverty along fetching the foreign exchange in the economy. It is expected that by upgrading the women labor force to the self-employed, the effects on the targeted level of development will be commendable. The significance of the selfemployed women in the development of the economy is much sound.

\section{End Notes}

1. an American business women, philanthropist and co-founder of Gates Foundation addressed while announced ranked third in Forbes 2014 lists of the 100 Most Powerful Women.

2. decreased from $43.5 \%$ of the preceding fiscal year

3. as this year 6 schemes are announced to lubricate the concept by Prime Minister

4. in this era reforms are observed in tariff and trade culture, Pakistan make its first attempt to openness of trade in this era too

5. www.worldbank.org/database

6. Abdullah, Zhou D. ,Ali S.K., Jibran K. and Ali A.(2015),"Agricultural Credit in Pakistan: Past Trends and Future Prospects", Journal of Applied Environmental and Biological Sciences 5(12).

7. World Bank Poverty Estimaters 2010.

\section{References}

Abdullah, Zhou D., Ali S.K., Jibran K. \& Ali A. (2015). Agricultural Credit in Pakistan: Past Trends and Future Prospects, Journal of Applied Environmental and Biological Sciences, vol.5:12.

Arif, (2001). Effect of Micro Credit Disbursed by ADBP on Agricultural Production in District Attock, Institute of Dev. Studies, Faculty of Rural Social Sci., NWFP Agric. Univ. Peshawar, Pakistan.

Balgamwala M., Gazdar H. \& Bux H. Mallah (2014). Synergy or Trade-off between Agricultural Growth and Nutrition: Women's Work and Care, LANSA Working Paper Series, vol.2014.

Balgamwala M., Gazdar H. \& Bux H. Mallah (2015). Women's Agricultural Work \& Nutrition in Pakistan: Findings from Qualitative Research, LANSA Working Paper Series, vol.2015, No.02. 
Begum R. \& Yasmeen G. (2011). Contribution of Pakistani Women in Agriculture: Productivity and Constraints, Sarhad Journal of Agriculture, vol.27:4.

Block \& Wagner (2006). A Handbook of Research on Entrepreneurial Success and its Impact on Regional Development.

Borjas G.T. \& Bronars S.G (1989). Consumer Discrimination and Self-Employment, The Journal of Political Economy, vol.97:3, pp.581-605.

Butt T. M, Hassan Z.K, Mehmood K. \& Muhammad S. (2010). Role of Agricultural Development and their Constraints, Journal of Agriculture and Social Sciences, vol.9:68, pp.53-56.

Constant A. \& Zimmerman K. F. (2006), The Making of Entrepreneurs in Germany : Are Native Men \& Immigrants Alike?, Small Business Economics, vol.26, pp.279-300.

Deli F. (2011). Opportunity and Necessity Entrepreneurship: Local Unemployment and the Small Firm Effect, Journal of Management Policy and Practice, vol.12:4.

Economic Survey of Pakistan 2013-14.

Economic Survey of Pakistan 2014-15.

Evans D.S. \& Leighton L.S. (1989). Some Empirical Aspects of Entrepreneurship, The American Journal Review, vol.79:3, pp.519-535.

Fairlie R. (2011). Entrepreneurship, Economic Condition and the Great Recession, IZA Discussion Papers, No.5725.

Georgellis Y. \& Wall J. (2004). Gender Differences in Self-Employment, Federal Reserve Bank of St. Louis, Working paper 1999-008C.

Gillispie S. Harris J. \& Kadiyala S. (2012). The Agriculture Nutrition Disconnect in India: What do we know? IFPRI Discussion paper 01187.

Habib, S. (2015). Role of Institutional Credit on Agriculture in Pakistan, http://www.foodjournal.pk/2015/May-June-2015/PDF-May-June-2015/Exclusivearticle-on-Agricultural.pdf

Khan, A. (2007). Women and Paid Work in Pakistan, Pathways of Women's Empowerment, South Asia Research Program, Pakistan Scoping Paper. 
Khan, N., Muhammad, M. Shafi, Shah, M., Islam, Z., Arif, M., Javed, R. \& Shah, N. (2011). Review of Past Literature on Agriculture Credit in Rural Area of Pakistan, Sarhad Journal of Agriculture, vol.27:1.

Labour Force Survey 2013-14, Pakistan Bureau of Statistics.

Labour Force Survey 2014-15, Pakistan Bureau of Statistics.

Lal, R. \& Khurana A. (2011). Gender Issue: The Role of Women in Agriculture Sector, International Journal of Business Economics and Management Research, vol.1:1, pp.29-39.

Le Anh T. (1996). Self-Employment \& Earnings among Immigrants in Australia, International Immigrants, vol.37, pp.383-412.

Le Anh T. (2000). The Difference of Immigrant Self-Employment in Australia, The International Migration Review, vol.34:1.

Lofstrom, M. (2009). Does Self-employment Increase the Well-Being of Low-Skilled Workers? IZA Discussion Papers, No.4539.

Prakash, T.N. (2003). Land Suitability Analysis for Agricultural Crops: A Fuzzy Multi Criteria Decision Making Approach, A Thesis Submitted to International Institute for Geo-Information Science and Earth Observation.

Rees, H. \& Shah, A. (1986). An Empirical Analysis of Self-Employment in the UK, Journal of Applied Econometrics, vol.1, pp.101-108.

Trang Do T. Q. \& Duchene, G. (2008). Determinants of Self-Employment: The Case in Vietnam, CES Working Paper No.38.

Waqar, M. (2002). Effects of SRSPs Micro-Enterprise Development Program on Income and Employment. Thesis of M.Sc (Hons) Agric. Univ. Peshawar, Pakistan.

Women in agriculture in Pakistan, Annual report of Food and Agriculture Organization of the United Nations 2015.

World Bank Poverty Estimators 2010. 
Zahir, M. Faridi, Sharif, I. Chaudhry \& Shoukat, M. Malik (2011). Why Women are SelfEmployed? Empirical Evidence from Pakistan, International Journal of Economics and Finance, vol.3:1.

Dr. Rummana Zaheer is an Assistant Professor in the Department of Economics, University of Karachi.

Saman Hussain is Ph.D Student in the Department of Economics, University of Karachi.

Dr. Muhammad Nadeemullah is an Associate Professor in the Department of Social Work, University of Karachi. 